\title{
EFEKTY MEDIACYJNE W KONTEKŚCIE NABYWANIA I EKSPLOATACJI WIEDZY ZEWNĘTRZNEJ CZYNNIKIEM SUKCESU W ROZWOJU ORGANIZACJI
}

https://doi.org/10.33141/po.2019.04.08

\section{Monika Stelmaszczyk, Szymon Jopkiewicz}

Przegląd Organizacji, Nr 4 (951), 2019, ss. 51-58 www.przegladorganizacji.pl @Towarzystwo Naukowe Organizacji i Kierownictwa (TNOiK)

\section{Wprowadzenie}

K ażda organizacja absorbuje wiedzę ze źródeł zewnętrznych. Często jest to celowe działanie postrzegane w kategoriach zasadniczego czynnika sukcesu wspierającego rozwój. Te organizacje świadomie podejmują aktywności mające na celu nabywanie i eksploatację wiedzy z zewnątrz. Są też takie, które nie koncentrują swojej uwagi na wysiłkach ukierunkowanych $\mathrm{w}$ ten sposób, ograniczając tym samym swój wzrost.

Ponadto niektórzy badacze prezentują pogląd, że przewaga konkurencyjna nie jest uzależniona tak bardzo od posiadanych zasobów wewnętrznych, jak od umiejętności identyfikacji i nabywania cennej wiedzy zewnętrznej oraz wykorzystywania jej w praktyce (Leiponen, Helfat, 2010, s. 224-236; Segarra-Ciprés i in., 2014, s. 203-2014). Wynika to $\mathrm{z}$ faktu, że organizacje nie dysponują w całości takimi zasobami wiedzy, których potrzebują. Są zmuszone do tworzenia poza swoimi granicami sieci powiązań, żeby w oparciu o nie zdobywać wiedzę. Ze względu na taki kontekst konkurencyjności pozyskiwanie wiedzy ze źródeł zewnętrznych oraz umiejętność stosowania jej w praktyce mają obecnie fundamentalne znaczenie dla funkcjonowania i rozwoju organizacji.

Identyfikacja i nabywanie wiedzy zewnętrznej oraz jej eksploatacja osadzone są w koncepcji zdolności absorpcyjnej. Stanowi ona podstawę rozważań prezentowanych w niniejszym artykule. Polega na uznaniu wartości wiedzy znajdującej się w otoczeniu organizacji, przyswojeniu jej oraz wykorzystaniu do realizacji wytyczonych celów (Tortoriello, 2015, s. 586-597; Stelmaszczyk, 2018b, s. 63). Na gruncie zarządzania strategicznego koncepcja zdolności absorpcyjnej spotyka się $\mathrm{z}$ dużym zainteresowaniem. Mimo szerokiej skali i zróżnicowanych obszarów badawczych, niedostatecznie wyjaśnioną kwestią pozostaje identyfikacja zmiennych, które mogłyby pośredniczyć w drodze, jaką przebywa wiedza zewnętrzna od momentu nabycia do wykorzystania jej w praktyce (do podjęcia działań eksploatacyjnych). Zadaniem badaczy jest więc doprecyzowanie mechanizmu transferu wiedzy, począwszy od wejścia w jej posiadanie do eksploatacji - mechanizmu, dzięki któremu nowa wiedza nabywana $\mathrm{z}$ zewnątrz jest osadzana w pamięci i strukturze organizacyjnej.

W zaprezentowanych rozważaniach nie skoncentrowano się więc tylko i wyłącznie na tym, jak nowo nabyta wi- dza usprawnia działania eksploatacyjne. Przede wszystkim podjęto próbę wyjaśnienia, dlaczego taka prawidłowość zachodzi. Potraktowanie asymilacji i transformacji nowo nabytej wiedzy w kategorii zmiennych, które powinny zaistnieć, żeby użyteczna wiedza zewnętrzna mogła być lepiej wykorzystana przez organizację, da możliwość zrozumienia badanego zjawiska. Pozwoli wyjaśnić, dlaczego ono zachodzi i jak działa. Postanowiono zatem udowodnić, że im bardziej organizacja będzie zaangażowana $\mathrm{w}$ asymilację nowej wiedzy (analizę i zrozumienie) oraz jej transformację (łączenie nowej wiedzy $\mathrm{z}$ dotychczasową), tym więcej wartościowej wiedzy nabytej z zewnątrz wykorzystywać będzie do realizacji wytyczonych celów (do eksploatacji).

W związku z tym celem niniejszych rozważań jest zbadanie zależności występujących pomiędzy nabyciem i eksploatacją wiedzy zewnętrznej przy uwzględnieniu roli, jaką odgrywa asymilacja i transformacja tej kategorii zasobu.

\section{Od nabycia do eksploatacji wiedzy zewnętrznej - efekt podwójnej mediacji}

\section{Nabycie a eksploatacja wiedzy}

$\mathbf{N}$ abywanie wiedzy zewnętrznej zdefiniować należy jako umiejętność identyfikowania oraz wchodzenia w posiadanie wartościowej wiedzy pochodzącej ze źródeł zewnętrznych, w procesie ciągłego jej wyszukiwania (Pedrosa i in., 2013, s. 254-273). Dzięki rozwiniętej umiejętności nabywania wiedzy organizacje mogą rozpoznawać i uzyskiwać dostęp do cennego zasobu, który jest im niezbędny w procesie realizacji wytyczonych celów.

Wiedza pochodząca $\mathrm{z}$ zewnątrz może być nabywana przez organizację drogą włączania nowych uczestników (np. zatrudniania specjalistów w danej dziedzinie), organizacyjnych eksperymentów, benchmarkingu, kursów, warsztatów, konferencji itp. (Parra-Requena i in., 2015, s. 152). Ważną rolę odgrywa także nawiązywanie współpracy z podmiotami zewnętrznymi (Pierścieniak, 2014, s. 119-128). Zewnętrzne źródła pozyskiwania wiedzy obejmują szeroki zakres mechanizmów, takich jak zewnętrzne prace badawczo-rozwojowe, pozyskiwanie patentów i licencji, sojusze strategiczne (Simonin, 1999, s. 595-623) oraz inne formy współpracy, wśród których na szczególną uwagę zasługuje „collaboration” i „cooperation” (Pierścieniak, 2015, 66-93). Nabywanie tej 
kategorii zasobu odbywa się w oparciu o zewnętrzne i wewnętrzne relacje, które dostarczają wiedzy o różnym charakterze oraz obejmują działania formalne i nieformalne.

Stopień, w jakim organizacja nabywa nową wiedzę zewnętrzną, uzależniony jest od wielu czynników. Wśród nich W.M. Cohen i D.A. Levinthal (1990, s. 128-152) wskazali na wiedzę, która znajduje się w posiadaniu organizacji; umiejętności rozpoznania i oceny wartościowej wiedzy zewnętrznej; wielokrotność i intensywność interakcji pomiędzy daną organizacją a jej kluczowymi partnerami oraz gotowość podmiotów zewnętrznych do dzielenia się informacjami. We współczesnej literaturze z zakresu zarządzania strategicznego podkreślana jest również rola przepływów wiedzy menedżerskiej (Stelmaszczyk, 2018a), ambidexterity (wyrażone równoczesną realizacją dwóch przeciwstawnych aktywności organizacyjnych, tj. wymiany wiedzy i ochrony wiedzy), jak również otwartości na wiedzę (Stelmaszczyk, Jarubas, 2019).

Jednak samo nabycie wiedzy zewnętrznej, oznaczające wejście $\mathrm{w}$ jej posiadanie, stanowi dopiero połowę sukcesu. Organizacja po nabyciu zasobu o kluczowym znaczeniu dla podejmowanych przez nią aktywności powinna podjąć kroki związane z eksploatacją (Presutti i in., 2011, s. 361-389). Jest to zastosowanie nowej wiedzy w praktyce (Zahra, George, 2002, s. 189). Umożliwia rozbudowę istniejących oraz tworzenie nowych kompetencji w oparciu o nabytą wiedzę zewnętrzną (Naqshbandi, Kamel, 2017, s. 5-20). Zgodnie z koncepcją zdolności absorpcyjnej, eksploatację można więc sprowadzić do dwóch kategorii: tej, która polega na wykorzystaniu $\mathrm{w}$ praktyce wiedzy nowej dla organizacji, oraz tej, która w oparciu o nowo nabytą wiedzę zwiększa wykorzystanie i rozwój wiedzy już znanej, prowadząc do jej udoskonalenia.

Autorzy oczekują więc, że nabywanie wiedzy zewnętrznej usprawniać będzie działania eksploatacyjne. Tym bardziej, że H. Yli-Renko, E. Autio i H.J. Sapienza (2001, s. 587-613) wykazali w swoich badaniach przeprowadzonych na próbie 180 przedsiębiorstw wykorzystujących zaawansowane technologie w Wielkiej Brytanii, że nabycie wiedzy ze źródeł zewnętrznych bezpośrednio oddziałuje na eksploatację tej kategorii zasobu. Co więcej, P. Junni (2011, s. 307-321) udowodniła, że strach przed eksploatacją posiadanej wiedzy przez drugą stronę (inną organizację) wywołuje bardzo silną niechęć do nabywania od niej nowej wiedzy (badania przeprowadzone zostały $\mathrm{w}$ fińskich przedsiębiorstwach). Utrudniony jest dostęp do badań, które odnosiłyby się do tego typu zależności w innych typach organizacji, np. w organizacjach publicznych. Świadczyć to może o ich mocno ograniczonym charakterze.

Uwzględniając dotychczasowe rozważania, zaproponowano hipotezę, która stanowi punkt wyjścia do dalszych rozważań:

H1: Istnieje pozytywna zależność pomiędzy nabyciem a eksploatacją wiedzy zewnętrznej.

\section{Asymilacja i transformacja w roli mediatorów}

Samo nabycie wiedzy nie gwarantuje, że zasób ten zostanie wykorzystany przez organizację, która go pozyskała albo że będzie przez nią zaakceptowany. Oczywiście wyniki do- tychczasowych badań świadczą o występowaniu bezpośredniej zależności pomiędzy nabyciem a eksploatacją. Może to oznaczać, że im więcej wiedzy zewnętrznej pozyska organizacja, tym większą jej ilość wykorzysta w praktyce. Innymi słowy, założono, że eksploatacja wiedzy uzależniona jest od jej nabycia.

Biorąc jednak pod uwagę koncepcję zdolności absorpcyjnej zaproponowaną przez S.A. Zahraę i G. George’a (2002, s. 185-203), zauważono, że nowo nabyta wiedza zanim znajdzie zastosowanie w praktyce (eksploatacja), zostaje poddawana swoistego rodzaju czynnościom związanym $\mathrm{z}$ asymilacją i transformacją ${ }^{1}$. Asymilacja sprowadza się do przyswojenia zasobu wiedzy, który został nabyty z zewnątrz. Występuje wówczas, gdy uczestnicy organizacji podejmują działania związane $\mathrm{z}$ analizą, interpretacją i zrozumieniem nowo zinternalizowanej wiedzy (Batarseh i in., 2017, s. 1342-1361). Z kolei transformacja polega na łączeniu dotychczas posiadanej wiedzy $\mathrm{z}$ nowo nabytą i przyswojoną wiedzą zewnętrzną (Zahra, George, 2002, s. 189).

$\mathrm{Na}$ gruncie zarządzania strategicznego wielu badaczy utożsamia nabycie, asymilację, transformację i eksploatację wiedzy zewnętrznej ze zdolnością absorpcyjną (Zahra, Georgre, 2002, s. 189; Flatten i in., 2011, 98-116; Hodgkinson i in., 2012, s. 211-229; Ramachandran, 2018, s. 1844-1864). Postrzegają ją w kategorii procesu, którego poszczególne elementy pełnią niezależne funkcje. Tym samym traktowane są jako cztery oddzielne etapy. Takie podejście pozwoliło zdiagnozować wpływ każdego etapu na wyniki funkcjonowania organizacji. Stworzyło także warunki do poszukiwania antecedencji każdego z nich. Jednak badanie relacji występujących pomiędzy wskazanymi elementami zdolności absorpcyjnej należy obecnie do rzadkości. Aspekt oddziaływania asymilacji na transformację nie został dotychczas uwzględniony w kontekście czynników mediujących zależność występującą pomiędzy nabyciem a eksploatacją. Mimo że badania nad zdolnością absorpcyjną prowadzone są na szeroką skalę i w różnych obszarach problemowych, rzadko podchodzi się do niej z perspektywy efektu podwójnej mediacji. W niniejszych rozważaniach zasugerowano więc, że wewnętrzna umiejętność asymilacji i transformacji jest niezbędna do tego, żeby organizacja mogła wykorzystać $\mathrm{w}$ praktyce nowo nabytą wiedzę zewnętrzną na takim poziomie efektywności, na jakim eksploatuje pozostałe zasoby. Innymi słowy, przypisanie asymilacji i transformacji roli mediatorów w zależności występującej pomiędzy zmienną niezależną (nabyciem) a zmienną zależną (eksploatacją) stanowi wartość dodaną niniejszych rozważań. Równoczesne wprowadzenie do modelu dwóch zmiennych pośredniczących pozwoli na wyjaśnienie, dlaczego zależność między nabyciem i eksploatacją zachodzi oraz jak działa. W związku z tym sformułowano hipotezę:

H2: Asymilacja oraz transformacja sa mediatorami zależności między nabyciem wiedzy zewnętrznej a jej eksploatacja.

$\mathrm{Na}$ potrzeby niniejszych rozważań zbudowano model teoretyczny wyjaśniający układ relacji pomiędzy nabyciem a eksploatacją wiedzy zewnętrznej przy uwzględnieniu asymilacji i transformacji w roli mediatorów (rys. 1). 


\section{Wyniki badań empirycznych}

\section{Metoda badawcza}

0 biektem badań jest Urząd Marszałkowski Województwa Świętokrzyskiego. Jako organizacja publiczna (wojewódzka samorządowa jednostka organizacyjna) prowadzi swoją działalność na terenie wspomnianego województwa. Stanowi aparat pomocniczy w realizowaniu zadań marszałka, zarządu oraz sejmiku województwa. Dąży do osiągania wytyczonych celów zgodnie $\mathrm{z}$ przyjętą polityką rozwoju społeczno-gospodarczego. Podejmuje aktywności w sferze edukacji publicznej, kultury, promocji i ochrony zdrowia, pomocy społecznej, polityki prorodzinnej, zagospodarowania przestrzennego, dróg publicznych i transportu, kultury fizycznej i turystyki, modernizacji terenów wiejskich, ochrony środowiska, gospodarki wodnej, ochrony praw konsumenta, bezpieczeństwa publicznego, obronności, przeciwdziałania bezrobociu, jak również aktywizacji lokalnego rynku pracy.

Na gruncie nauk o zarządzaniu i jakości najdokładniej rozpoznane zostały kwestie związane $\mathrm{z}$ funkcjonowaniem przedsiębiorstw (Kożuch, 2017, s. 99). Ten rodzaj organizacji najczęściej występuje w gospodarce rynkowej. Jednak organizacje publiczne różnią się od przedsiębiorstw wieloma istotnymi cechami. Zasady oraz warunki sprawnego ich funkcjonowania i rozwoju należą do obszarów słabiej rozpoznanych. Wiedza na ten temat jest niekompletna i rozproszona. Stąd też postanowiono poznać i wyjaśnić kwestie związane z nabywaniem i eksploatacją wiedzy zewnętrznej $\mathrm{w}$ jednej $\mathrm{z}$ dużych organizacji publicznych, tj. w Urzędzie Marszałkowskim Województwa Świętokrzyskiego.

Badanie zostało przeprowadzone na przełomie września i października 2018 roku. Do pomiaru zależności pomiędzy nabyciem wiedzy zewnętrznej a jej eksploatacją posłużono się kwestionariuszem ankiety. W badaniu wykorzystano siedmiopunktową skalę Likerta, począwszy od (1) „zdecydowanie NIE” do (7) „zdecydowanie TAK”. Kwestionariusz ankiety został skierowany do osób, które w badanej organizacji pełniły funkcje kierownicze. Łącznie otrzymało go 86 respondentów. Po usunięciu tych kwestionariuszy, które miały brakujące dane oraz sprzeczne lub niedające się wyjaśnić odpowiedzi, uzyskano 71 ważnych obserwacji. Taką ich liczbę przyjęto do analiz.

Wśród 71 respondentów 56,3\% stanowiły kobiety, natomiast $43,7 \%$ mężczyźni. W przedziale od 18 do 25 roku życia znajdowało się $38 \%$, podczas gdy $36,6 \%$ zadeklarowało, że jest pomiędzy 26 a 40 rokiem życia, natomiast $25,4 \%$ - między 41 a 50. Ponadto $33,8 \%$ badanych obejmowało stanowisko dyrektora lub wicedyrektora komórki organizacyjnej, $42,3 \%$ - kierownika oddziału oraz 23,9\% koordynatora wie- loosobowego stanowiska. Dane dotyczące stażu pracy w badanej organizacji zaprezentowano $\mathrm{w}$ tabeli 1 . Zwraca uwage fakt, że aż 80\% respondentów pracuje w tej organizacji 6 lat lub dłużej.

Tabela 1. Staż pracy - charakterystyka próby badawczej

\begin{tabular}{|c|c|c|c|}
\hline & & Częstość & $\%$ \\
\hline \multirow{3}{*}{$\begin{array}{c}\text { Staż pracy } \\
\text { ogółem }\end{array}$} & $2-3$ lata & 3 & 4,2 \\
\hline & $4-5$ lat & 11 & 15,5 \\
\hline & 6 lat i dłużej & 57 & 80,3 \\
\hline \multirow{4}{*}{$\begin{array}{c}\text { Staż pracy } \\
\text { na obecnie } \\
\text { zajmowanym } \\
\text { stanowisku }\end{array}$} & 1 rok i krócej & 8 & 11,3 \\
\hline & 2-3 lata & 27 & 38,0 \\
\hline & $4-5$ lat & 13 & 18,3 \\
\hline & 6 lat i dłużej & 23 & 32,4 \\
\hline
\end{tabular}

Źródto: opracowanie własne

W Urzędzie Marszałkowskim Województwa Świętokrzyskiego wiodącym źródłem nabywania wiedzy pochodzącej ze źródeł zewnętrznych są przede wszystkim szkolenia. Aż $86 \%$ respondentów wskazało na celowe pozyskiwanie wiedzy z zewnątrz w ten oto sposób. Na drugie miejsce wysunęła się prasa i wydawnictwa specjalistyczne oraz współpraca $z$ innymi instytucjami z branży. Cenioną przez Urząd wiedzą zewnętrzną jest również ta, którą pozyskuje on poprzez kontakty z ekspertami (specjalistami) w danej dziedzinie. $\mathrm{W}$ opinii ok. 70\% badanych jest to istotne źródło pozyskiwania wiedzy. W granicach $60 \%-65 \%$ respondentów wskazało również na: a) zakup komputerowych baz danych i/lub oprogramowania, b) imprezy branżowe oraz c) uczenie się od konkurentów, np. poprzez monitorowanie ich stron internetowych. Na uwagę zasługuje także współpraca z instytucjami naukowo-badawczymi, głównie uczelniami wyższymi. $\mathrm{W}$ opinii $50 \%$ respondentów badana organizacja nabywa wiedzę zewnętrzną $\mathrm{z}$ tego źródła. Tymczasem rzadko pozyskuje wiedzę zewnętrzną poprzez zastosowanie metod pracy zaobserwowanych $\mathrm{w}$ innych organizacjach. Sporadycznie nabywa wiedzą od klientów, jak również drogą zatrudniania nowych pracowników w celu uzupełnienia lub poszerzenia wiedzy organizacyjnej.

Jak widać, poddany badaniu urząd identyfikuje i nabywa wiedzę ze źródeł zewnętrznych. Są one zróżnicowane oraz wykorzystywane z różną częstotliwością. Jednak samo wejście w posiadanie wiedzy zewnętrznej oznacza dopiero połowę sukcesu. Żeby cenny zasób mógł być wykorzystany do realizacji wytyczonych celów, musi zostać poddany

H2 Efekt podwójnej mediacji

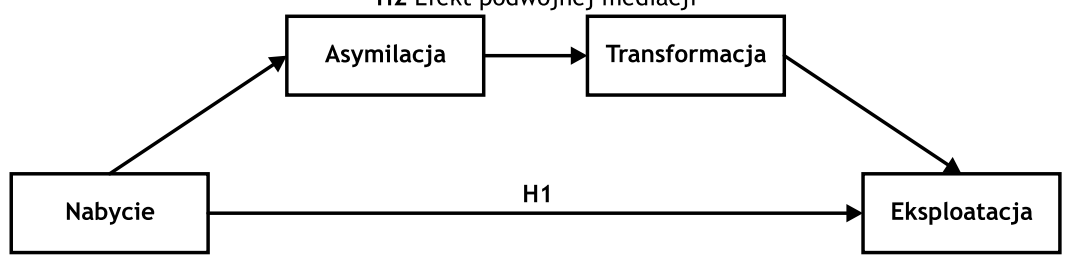

Rys. 1. Model opisujący cel gtówny pracy

Źródło: opracowanie własne 
eksploatacji. Innymi słowy, badana organizacja musi zastosować w praktyce nowo nabytą wiedzę. Niestety, tylko $16,9 \%$ respondentów jest przekonanych, że urząd potrafi zastosować w praktyce nowo pozyskany zasób wiedzy. Zaledwie 15,5\% badanych jest pewnych co do tego, że ich organizacja pracuje efektywniej wtedy, kiedy wykorzystuje nowe pomysły i koncepcje działania. Tymczasem większość wyłącznie przypuszcza, że tak właśnie jest. To znaczy około $75 \%$ pytanych osób jest skłonnych wypowiedzieć się pozytywnie w tej kwestii, mimo że niejednokrotnie byli świadkami marnotrawienia nowo pozyskanej wiedzy czy też braku zastosowania jej w praktyce.

W związku z powyższym istnieją przesłanki pozwalające przypuszczać, że nie każda nowo pozyskana przez urząd wiedza zewnętrzna znajduje zastosowanie w praktyce. Mając więc na uwadze koncepcję zdolności absorpcyjnej, można domniemywać, że przyczyna zaistniałego zjawiska wynika $\mathrm{z}$ trudności lub niechęci do przeprowadzenia analizy, interpretacji czy zrozumienia nowo nabytej wiedzy zewnętrznej (asymilacja), czy też problemów związanych z łączeniem wiedzy dotychczasowej z nowo nabytą (transformacja).

Na potrzeby badań empirycznych wyodrębniono następujące rodzaje zmiennych: zmienną niezależną, zmienną zależną oraz dwa mediatory (zmienne pośredniczące). Do ich pomiaru zaadoptowano skalę opracowaną przez T.C. Flatten i innych (2011, 98-116). Autorzy przygotowali ją w celu potwierdzenia słuszności koncepcji mówiącej o tym, że zdolność absorpcyjną należy traktować jako zmienną wielowymiarową. Tym samym uwzględnili nabycie, asymilację, transformację i eksploatację. Przeprowadzili dogłębne badania literaturowe, serię testów wstępnych oraz dwa duże badania przedsiębiorstw niemieckich. Obecnie skala ta wykorzystywana jest przez bardzo dużą liczbę badaczy prowadzących swoje dociekania empiryczne $\mathrm{w}$ różnych typach organizacji na całym świecie.

Zmienna niezależna. Nabywanie wiedzy zewnętrznej jest umiejętnością identyfikowania oraz wchodzenia w posiadanie wartościowej wiedzy pochodzącej ze źródeł zewnętrznych, w procesie ciągłego jej wyszukiwania (Pedrosa i in., 2013, s. 254-273). Do pomiaru tej zmiennej wykorzystano 3 itemy, za pomocą których zmierzono stopień, w jakim organizacja angażuje się w poszukiwanie oraz wchodzenie w posiadanie wiedzy znajdującej się poza jej granicami. Wartość Alfa-Cronbacha dla tej zmiennej wyniosła 0,70.

Zmienna zależna. Eksplorację wiedzy rozumieć należy jako zastosowanie nabytej wiedzy w praktyce (Zahra, George, 2002, s. 189). Stosując 3-itemową skalę, zmierzono, czy organizacja wykorzystuje w praktyce nowo nabytą wiedzę oraz czy dzięki nowo nabytej wiedzy udoskonala wiedzę, którą już posiada (zwiększając jej wykorzystanie i rozwój). Wartość Alfa-Cronbacha dla eksploatacji wyniosła 0,61.

Mediatory. Asymilacja to przyswojenie zasobu wiedzy, który został nabyty z zewnątrz (Batarseh i in., 2017, s. 1342-1361). Ocenie respondentów poddane zostały 4 itemy, za pomocą których zmierzono stopień, w jakim nabywana wiedza poddawana jest analizie, interpretacji i zrozumieniu. $Z$ kolei transformacja polega na łączeniu dotychczas posiadanej wiedzy $\mathrm{z}$ nowo nabytą i przyswojoną wiedzą zewnętrzną (Zahra, George, 2002, s. 189). Do pomiaru zmiennej wyko- rzystano 4-itemową skalę. Określono, czy organizacja potrafi połączyć wiedzę nową $\mathrm{z}$ wiedzą istniejącą oraz dostosować ją do swoich potrzeb. Wartość Alfa-Cronbacha dla asymilacji i transformacji wyniosła kolejno 0,73 oraz 0,91 .

W celu empirycznej weryfikacji hipotez badawczych wykonano analizy statystyczne, wykorzystując pakiet IBM SPSS Statistics w wersji 24. Najpierw przeprowadzono analizy podstawowych statystyk opisowych $\mathrm{z}$ testem normalności rozkładu Kołmogorowa-Smirnowa (K-S). Następnie wykonano szereg analiz prostych regresji liniowych łącznie $\mathrm{z}$ analizą mediacji, do czego wykorzystano narzędzie makro PROCESS Hayesa i Preachera. Ponadto na potrzeby interpretacji analiz przyjęto, że poziom istotności a wynosi 0,05 .

\section{Podstawowe statystyki opisowe mierzonych zmiennych ilościowych}

Analizę rozpoczęto od wyliczenia podstawowych statystyk opisowych. Sprawdzono także normalność rozkładu uwzględnionych w modelu zmiennych mierzonych na skali ilościowej. Wynik testu K-S świadczy o tym, że rozkład zbliżony do normalnego ma tylko jedna zmienna - asymilacja. Rozkłady pozostałych zmiennych są nieco odchylone od rozkładu normalnego. Jednak wartość skośności rozkładu (dla statystycznie istotnego wyniku testu K-S) nie przekracza progu 0,8 , co świadczy o tym, że rozkład każdej ze zmiennych jest stosunkowo symetryczny względem średniej (George, Mallery, 2010). Zbiorcze zestawienie wyliczonych statystyk opisowych i testu K-S przedstawiono w tabeli 2.

\section{Analiza podwójnej mediacji}

W następnej części analiz postanowiono sprawdzić, czy asymilacja i transformacja są istotnymi statystycznie mediatorami zależności pomiędzy nabyciem a eksploatacją. Do przetestowania modelu podwójnej mediacji wykorzystano makro PROCESS autorstwa Hayesa i Preachera. Na rysunku 2 zobrazowano testowany model podwójnej mediacji.

Najpierw sprawdzono istotność zależności pomiędzy zmienną niezależną, tj. nabyciem wiedzy zewnętrznej a jej asymilacją. Otrzymane wyniki świadczą o tym, że zachodzący między tymi zmiennymi związek jest istotny statystycznie o dodatnim znaku $[F(1,69)=11,53 ; p=0,001 ; t(1,69)=3,395$; $p=0,001 ; \beta=0,378 ;$ S.E. $=0,111]$. Na podstawie nabycia można wyjaśnić $14,3 \%$ zmienności asymilacji $\left(\mathrm{R}^{2}=0,143\right)$.

Następnie do modelu wprowadzono zmienną określoną mianem transformacji. Z przeprowadzonych analiz wynika, że model uwzględniający nabycie i asymilację, jako zmienne niezależne oraz transformację, która przyjęła rolę zmienne zależnej, jest dobrze dopasowany do danych $[F(2,68)=28,43 ; p<0,001]$ i wyjaśnia $45 \%$ wariancji transformacji $\left(\mathrm{R}^{2}=0,455\right)$. Zarówno nabycie $[t(2,68)=2,223$; $p=0,0291 ; \beta=0,216$; S.E. $=0,097]$, jak i asymilacja $[t(2,68)=5,825 ; p<0,001 ; \beta=0,563$; S.E. $=0,097]$ są istotnymi predyktorami transformacji. Zależności te są dodatnie, co oznacza, że wraz ze wzrostem nabycia i asymilacji wzrasta poziom transformacji.

W kolejnym kroku do modelu dodano eksploatację, która wystąpiła w roli zmiennej zależnej, podczas gdy pozostałe zmienne (nabycie, asymilacja i transformacja) potraktowane zostały jako zmienne niezależne. Okazało się, że mo- 
del ten wyjaśnia 61,3\% zmienności eksploatacji zasobów wiedzy $\left(\mathrm{R}^{2}=0,613\right)$ i jest dobrze dopasowany do danych $[F(3,67)=35,32 ; p<0,001]$.

Należy także zaznaczyć, że współczynniki regresji dla poszczególnych zmiennych niezależnych przyjęły wartości dodatnie $\mathrm{i}$ istotne statystycznie [nabycie wiedzy zewnętrznej $-t(3,67)=3,972 ; p<0,001 ; \beta=0,338$; S.E. $=0,005$; asymilacja $-t(3,67)=3,819 ; p<0,001 ; \beta=0,384$; S.E. $=0,101$; transformacja $-t(3,67)=2,381 ; p=0,020 ; \beta=0,245$; S.E. $=0,103]$. Należy więc przypuszczać, że wzrost wyników tych zmiennych wywoływać będzie wzrost zmiennej zależnej. Ponadto bezpośrednia relacja pomiędzy nabyciem a eksploatacją wiedzy także jest istotna statystycznie i ma dodatni charakter $\left[F(1,69)=36,535 ; p<0,001 ; \mathrm{R}^{2}=0,346 ; t(1,69)=6,044 ; p<\right.$ $0,001 ; \beta=0,588 ;$ S.E. $=0,097]$. Wyniki przeprowadzonej analizy zaprezentowano w tabeli 3, natomiast wartości standaryzowanych współczynników regresji $\beta$ oraz współczynników R-kwadrat zilustrowano na rysunku 3.
Wyniki zaprezentowane w tabeli 3 świadczą o występowaniu trzech istotnych statystycznie efektów mediacyjnych: nabycie-asymilacja-eksploatacja, nabycie-transformacja-eksploatacja oraz nabycie-asymilacja-transformacja-eksploatacja. Zarówno asymilacja, jak i transformacja samodzielnie mediują zależność występującą pomiędzy nabyciem wiedzy zewnętrznej a jej eksploatacją. Wskaźniki obu efektów sygnalizują, że asymilacja może być silniejszym mediatorem niż transformacja. Istotnym statystycznie jest także efekt podwójnej mediacji. Ogólny efekt pośredniczący będący sumą trzech testowanych efektów jest także statystycznie istotny. W przedziałach ufności wygenerowanych na pomocą metody bootstrap autorstwa Hayesa i Preachera nie ma wartości 0 , co świadczy o istotności statystycznej poszczególnych efektów. Ponadto specyficzne efekty pośrednie uwzględniające różnice pomiędzy założonymi ścieżkami są nieistotne.

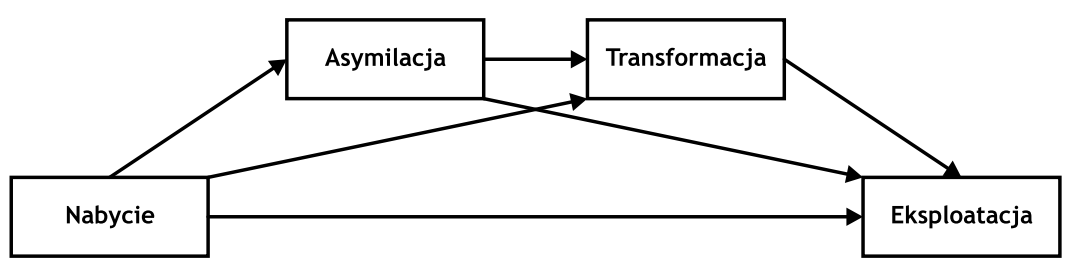

Rys. 2. Testowany model podwójnej mediacji Źródto: opracowanie własne

Tabela 2. Podstawowe statystyki opisowe oraz wynik testu K-S

\begin{tabular}{|c|c|c|c|c|c|c|c|c|c|}
\hline & $M$ & Mdn & SD & Sk. & Kurt. & Min. & Maks. & $\mathrm{K}-\mathrm{S}$ & $\mathrm{p}$ \\
\hline Nabycie & 16.87 & 17,0 & 2,63 & $-0,58$ & 1,15 & 9 & 21 & 0,15 & $<0,001$ \\
\hline Asymilacja & 18.92 & 19,0 & 3,93 & $-0,12$ & $-0,04$ & 10 & 28 & 0,08 & 0,200 \\
\hline Transformacja & 21,55 & 22,0 & 3,59 & $-0,27$ & $-0,07$ & 13 & 28 & 0,14 & 0,002 \\
\hline Eksploatacja & 16,32 & 16,0 & 2,11 & $-0,19$ & 0,55 & 10 & 21 & 0,14 & 0,002 \\
\hline
\end{tabular}

M - średnia; Mdn - mediana; SD - odchylenie standardowe; Sk. - skośność; Kurt. - kurtoza; Min. i Maks. - najniższa i najwyższa wartość rozkładu; $K-S$ - wynik testu Kołmogorowa-Smirnowa; $p-$ istotność; *uwzględniona poprawka istotności Lillieforsa

Źródło: opracowanie wtasne

Tabela 3. Efekty mediacyjne w relacji między nabyciem a eksploatacją wiedzy zewnętrznej

\begin{tabular}{|c|c|c|c|c|}
\hline & & & & \\
\hline & \multirow[b]{2}{*}{ B } & \multirow[b]{2}{*}{ Boot SE } & \multicolumn{2}{|c|}{ 95\% Cl (bootstrap) } \\
\hline & & & LL & UL \\
\hline Total & 0,250 & 0,079 & 0,098 & 0,418 \\
\hline Ind 1 & 0,145 & 0,067 & 0,031 & 0,297 \\
\hline Ind2 & 0,053 & 0,026 & 0,008 & 0,110 \\
\hline Ind3 & 0,052 & 0,027 & 0,008 & 0,115 \\
\hline $\mathrm{C} 1$ & 0,092 & 0,77 & $-0,042$ & 0,258 \\
\hline $\mathrm{C} 2$ & 0,093 & 0,069 & $-0,022$ & 0,249 \\
\hline $\mathrm{C} 3$ & $<0,001$ & 0,030 & $-0,068$ & 0,055 \\
\hline
\end{tabular}

B - współczynnik niestandaryzowany regresji, Boot SE - błąd standardowy; LL i UL - dolna i górna granica przedziału ufności

Total - model podwójnej mediacji; Ind1 - nabycie > asymilacja > eksploatacja; Ind2 - nabycie > transformacja > eksploatacja; Ind3 - nabycie > asymilacja > transformacja > eksploatacja; C1 - Ind1 minus Ind2; C2 - Ind1 minus Ind3; C3 - Ind2 minus Ind3

Źródto: opracowanie wtasne 


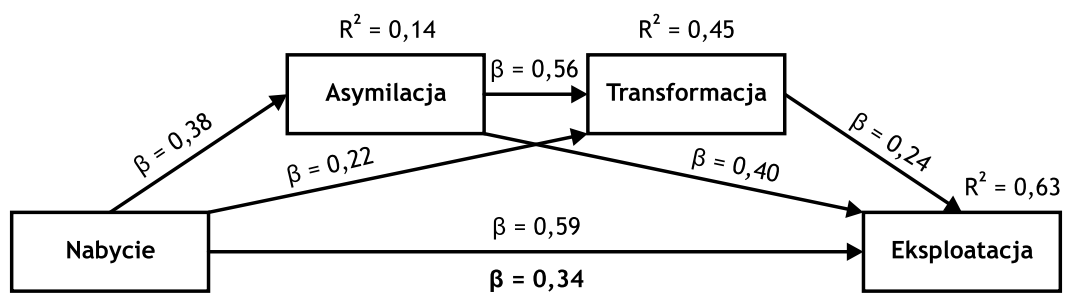

Rys. 3. Efekt podwójnej mediacji (asymilacji i transformacji) w zależności pomiędzy nabyciem a eksploatacją wiedzy zewnętrznej

Źródło: opracowanie wtasne ${ }^{2}$

Wyniki przeprowadzonych analiz pozwalają na przyjęcie hipotez H1 i H2. Oznacza to, że występuje istotna statystycznie, dodatnia bezpośrednia zależność pomiędzy nabyciem i eksploatacją wiedzy zewnętrznej. Stwierdzono również, że asymilacja i transformacja wiedzy zewnętrznej są istotnymi mediatorami tej zależności. Podwójna mediacja istotnie oddziałuje na związek między zmienną niezależną a zmienną zależną, wyraźnie go osłabiając. Po wprowadzeniu do modelu zmiennych pośredniczących zależność ta jest nadal istotna statystycznie. Świadczy to o występowaniu mediacji częściowej.

\section{Podsumowanie}

C elem niniejszych rozważań było zbadanie zależności występujących pomiędzy nabyciem i eksploatacją wiedzy zewnętrznej przy uwzględnieniu roli asymilacji i transformacji tej kategorii zasobu. Rozpoznano mechanizm, dzięki któremu nowa wiedza nabywana z zewnątrz jest osadzana w pamięci i strukturze organizacyjnej Urzędu Marszałkowskiego Województwa Świętokrzyskiego. Zwrócono uwagę na asymilację i transformację jako działania, które organizacja powinna podejmować, żeby użyteczna wiedza zewnętrzna w możliwie największym stopniu znajdowała zastosowanie w praktyce.

\section{Implikacje teoretyczne}

Wyniki przeprowadzonych analiz umożliwiły przyjęcie hipotez H1 i H2. W związku z tym teoretyczną implikacją przeprowadzonego badania jest potwierdzenie występowania istotnej statystycznie bezpośredniej, dodatniej oraz silnej zależności pomiędzy nabywaniem wiedzy zewnętrznej a jej eksploatacją. Dowodzi to, że im więcej wiedzy badana organizacja nabędzie, tym większa jej ilość zostanie wykorzysta w praktyce. Innymi słowy, wiedza zewnętrzna może usprawniać działania eksploatacyjne polegające na wykorzystywaniu w praktyce wiedzy nowej oraz udoskonalaniu za jej pomocą tej, która już znajduje się w posiadaniu organizacji (zwiększając jej wykorzystanie i rozwój). Wyniki otrzymane w organizacji publicznej - Urzędzie Marszałkowskim Województwa Świętokrzyskiego - potwierdziły rezultaty wcześniejszych badań, które zostały przeprowadzone przez H. Yli-Renko, E. Autio i H.J. Sapienza w przedsiębiorstwach prywatnych (2001, s. 587-613).

Wkładem w rozwój literatury z zakresu zarządzania strategicznego jest wskazanie efektu podwójnej mediacji w zależności pomiędzy nabyciem nowej wiedzy a jej eksploatacją. Oznacza to, że nabywanie przez urząd wiedzy zewnętrznej wywołuje wzrost asymilacji tego zasobu (pierwszy mediator), w wyniku czego wzrasta transformacja zasymilowanej wiedzy (drugi mediator), dzięki której dostrzegalna jest aktywizacja działań eksploatacyjnych. Z tego wynika, że badana organizacja tym więcej wartościowej wiedzy nabytej z zewnątrz wykorzystywać będzie do realizacji wytyczonych celów (do eksploatacji), im bardziej będzie zaangażowana w jej asymilację (analizę i zrozumienie) i transformację (łączenie nowej wiedzy $z$ dotychczasową).

Co ciekawe, silniejszą zależność zaobserwowano w przypadku pośredniczącej roli asymilacji niż transformacji. Może to świadczyć o tym, że w analizowanym przypadku to asymilacja odgrywa ważniejszą rolę podczas drogi, jaką powinna przebyć wiedza od momentu jej nabycia do wykorzystania w praktyce, tj. do podjęcia czynności eksploatacyjnych.

\section{Implikacje praktyczne}

Praktyczne implikacje przeprowadzonych analiz są następujące. Ci uczestnicy badanej organizacji, którzy obejmują w niej stanowiska kierownicze, powinni zwrócić szczególną uwagę na konieczność nabywania wiedzy ze źródeł zewnętrznych. Faktem jest, że obecnie większość organizacji nie posiada w całości takich zasobów wiedzy, których potrzebują do realizacji wytyczonych celów. Dlatego pozyskiwanie ich $\mathrm{z}$ zewnętrznych źródeł ma fundamentalne znaczenie również dla rozwoju Urzędu Marszałkowskiego Województwa Świętokrzyskiego.

Co więcej, naczelne kierownictwo powinno dbać nie tylko o wzbogacanie zasobów organizacyjnych wiedzą zewnętrzną, lecz także o zastosowanie jej w praktyce, czyli eksploatację. Jest ona, niestety, obarczona wieloma barierami, wśród których można wskazać np.: brak akceptacji nowej wiedzy ze strony niektórych pracowników i związane z nią odrzucanie wartościowego zasobu, koszty związane ze złożonością zarządzania zróżnicowaną wiedzą, jak też rozwój tych zdolności, które umożliwią im eksploatację nabytej wiedzy.

Zatem kolejną praktyczną implikacją otrzymanych wyników jest dostarczenie naczelnemu kierownictwu pomysłu na to, jak wzmocnić zależność między nabyciem a eksploatacją wiedzy. Żeby wykorzystywać w praktyce nową wiedzę zewnętrzną na pożądanym poziomie efektywności, powinni oni zwrócić szczególną uwagę na działania aktywizujące asymilację (analizę i zrozumienie) oraz transformację (łączenie nowej wiedzy $\mathrm{z}$ dotychczasową) nabytego zasobu. Asymilacja okazała się być silniejszym mediatorem oraz w sposób bezpośredni silnie i dodatnio oddziałuje na transformację. W związku z tym zasugerowano, że w pierwszej kolejności właśnie ona wymagałaby usprawnienia i udoskonalenia. 
W tym celu naczelne kierownictwo mogłoby zorganizować wykłady pozwalające lepiej zrozumieć nowo nabytą wiedzę, przeprowadzić ukierunkowane dyskusje, zlecić pracę z precyzyjnie dobraną literaturą, zastosować storytelling czy też obserwację.

\section{Ograniczenia i kierunki przyszłych badań}

Sformułowane wnioski stanowiące wkład do teorii i praktyki należy interpretować przez pryzmat następujących ograniczeń. Pierwszym z nich jest ujęcie eksploatacji wiedzy w kategorii zmiennej jednowymiarowej. Podejście to jest zgodne z koncepcją zdolności absorpcyjnej organizacji. Jednak zastosowanie w tym przypadku kilku wymiarów mogłoby prowadzić do wniosków charakteryzujących się wyższym poziomem szczegółowości oraz wzrostem zainteresowania ze strony praktyków zarządzania. Wobec tego kierunkiem przyszłych badań mogłoby być opisanie tej zmiennej za pomocą dwóch wymiarów. Jeden dotyczyłby wykorzystywania w praktyce zupełnie nowej wiedzy, drugi - odnosiłby się do aktywności, które poprzez zastosowanie nowo nabytej wiedzy, udoskonalałyby tę, która już znajduje się w posiadaniu organizacji (zwiększając jej wykorzystanie i generując rozwój).

Drugie ograniczenie związane jest $\mathrm{z}$ tym, że badaniem objęto tylko jedną organizację. Otrzymanych wyników nie można zatem uogólniać na całą populację urzędów marszałkowskich funkcjonujących na terenie Polski.

Trzecie ograniczenie dotyczy mediacji częściowej, którą zaobserwowano w badanym przypadku. Oznacza to, że asymilacja (analiza i zrozumienie nowej wiedzy) oraz transformacja (łączenie nowej wiedzy z dotychczasową) odgrywają bardzo istotną rolę w eksploatacji nowo nabytej wiedzy zewnętrznej (wykorzystywaniu w praktyce). Jednak oprócz nich występują jeszcze inne zmienne, które nie zostały uwzględnione w badaniu. Sugerując się koncepcją zdolności absorpcyjnej, ograniczono się tylko i wyłącznie do jej wymiarów i założono, że rozpoznanie zależności występujących między nimi dostarczy odpowiedzi na nurtujące pytania. Rzeczywistość okazała się jednak inna. Zatem kierunkiem przyszłych badań powinno być poszukiwanie dodatkowych zmiennych, o które należałoby wzbogacić zaproponowany model. Warunkiem idealnym, lecz bardzo trudnym do osiągnięcia, byłoby otrzymanie mediacji całkowitej. Miałaby ona miejsce wówczas, gdyby udało się wskazać wszystkie zmienne, których zaistnienie wywoływałoby intensyfikację eksploatacji wiedzy nabytej ze źródeł zewnętrznych.

\section{dr Monika Stelmaszczyk Uniwersytet Jana Kochanowskiego w Kielcach Wydział Prawa, Administracji i Zarządzania ORCID: 0000-0002-7055-0193 e-mail: m.stelmaszczyk@ujk.edu.pl}

\author{
dr Szymon Jopkiewicz \\ Uniwersytet Jana Kochanowskiego w Kielcach \\ Wydziat Prawa, Administracji i Zarządzania \\ ORCID: 0000-0001-5289-6820 \\ e-mail: szymon.jopkiewicz@ujk.edu.pl
}

\section{Przypisy}

1) Zdolność absorpcyjna jest dynamiczną zdolnością organizacji osadzoną w jej systemach, procedurach i procesach, która dotyczy nabywania, asymilacji, transformacji oraz eksploatacji wiedzy zewnętrznej (Zahra, George, 2002, s. 189). Zdaniem autorów tej definicji, każdy ze wskazanych wymiarów jest odrębną zdolnością organizacyjną.

2) Zaprezentowana na rysunku wartość dla każdej kolejnej ścieżki jest współczynnikiem standaryzowanym $\beta$. Wynik zapisany pogrubioną czcionką oznacza związek między zmienną niezależną (nabyciem) a zmienną zależną (eksploatacją) przy równoczesnym uwzględnieniu obu mediatorów (asymilacji i transformacji).

\section{Bibliografia}

[1] Batarseh F.S., Usher J.M., Daspit J.J. (2017), Absorptive Capacity In Virtual Teams: Examining The Influence On Diversity And Innovation, „Journal of Knowledge Management”, Vol. 21, No. 6, pp. 1342-1361.

[2] Cohen W.M., Levinthal D.A. (1990), Absorptive Capacity: A New Perspective on Learning and Innovation, „Administrative Science Quarterly", Vol. 35, No. 1, pp. 128-152.

[3] Flatten T.C., Engelen A., Zahra S.A., Brettel M. (2011), A measure of absorptive capacity: Scale Development and Validation, „European Management Journal”, Vol. 29, No. 2, pp. $98-116$.

[4] George D., Mallery M. (2010), SPSS for Windows Step by Step: A Simple Guide and Reference, Pearson, Boston.

[5] Hodgkinson I.R., Hughes P., Hughes M. (2012), Absorptive Capacity and Market Orientation in Publicservice Provision, „Journal of Strategic Marketing", Vol. 20, No. 3, pp. 211-229.

[6] Junni P. (2011), Knowledge Transfer in Acquisitions: Fear of Exploitation and Contamination, „Scandinavian Journal of Management", Vol. 27, No. 3, pp. 307-321.

[7] Kożuch B. (2017), Nauka o organizacji, CeDeWu, Warszawa.

[8] Leiponen A., Helfat C.E. (2010), Innovation Objectives, Knowledge Sources, and the Benefits of Breadth, „Strategic Management Journal", Vol. 31, No. 2, pp. 224-236.

[9] Naqshbandi M.M., Kamel Y. (2017), Intervening Role of Realized Absorptive Capacity in Organizational Culture-open Innovation Relationship: Evidence from an Emerging Market, „Journal of General Management", Vol. 42, No. 3, pp. 5-20.

[10] Parra-Requena G., Ruiz-Ortega M.J., García-Villaverde, Pedro M., Rodrigo-Alarcón J. (2015), The Mediating Role of Knowledge Acquisition on the Relationship between External Social Capital and Innovativeness, „European Management Review”, Vol. 12, No. 3, pp. 149-169.

[11] Pedrosa A., Välling M., Boyd B. (2013), Knowledge Related Activities in Open Innovation: Managers' Characteristics and Practices, „International Journal of Technology Management”, Vol. 61, No. 3/4, pp. 254-273.

[12] Pierścieniak A. (2014), Czynniki sukcesu struktur wspótpracy nauki z praktyką, „Przedsiębiorczość i Zarządzanie”, t. 15, z. 10, cz. 2, s. 119-128.

[13] Pierścieniak A. (2015), Potencjał organizacji do wspótpracy zewnętrznej - ujęcie teoretycznie i metodyka pomiaru, Wyd. Uniwersytetu Rzeszowskiego, Rzeszów. 
[14] Presutti M., Boari C., Majocchi A. (2011), The Importance of Proximity for the Start-ups' Knowledge Acquisition and Exploitation, „Journal of Small Business Management”, Vol. 49, No. 3. pp. 361-389.

[15] Ramachandran I. (2018), Triggering Absorptive Capacity in Organizations: CEO Succession as a Knowledge Enabler, „Journal of Knowledge Management", Vol. 22, No. 8, pp. 1844-1864.

[16] Segarra-Ciprés M., Roca-Puig V., Bou-Llusar J.C. (2014), External Knowledge Acquisition and Innovation Output: An Analysis of the Moderating Effect of Internal Knowledge Transfer, „Knowledge Management Research \& Practice”, Vol. 12, No. 2, pp. 203-214.

[17] Simonin B.L. (1999), Ambiguity and the Process of Knowledge Transfer in Strategic Alliances, „Strategic Management Journal”, Vol. 20, No. 7, pp. 595-623.

[18] Stelmaszczyk M. (2018a), Oddziaływanie przeptywów wiedzy menedżerskiej na zdolność absorpcyjną organizacji, „Ekonomika i Organizacja Przedsiębiorstwa”, Nr 08(821), s. 85-97.

[19] Stelmaszczyk M. (2018b), W kierunku poprawy zdolności absorpcyjnej przedsiębiorstwa: efekt podwójnej mediacji, „E-Mentor", $\mathrm{Nr} 3(75)$, s. 63-71.

[20] Stelmaszczyk M., Jarubas A. (2019), Wymiana wiedzy czy ochrona wiedzy - a może ambidexterity? Perspektywa zdolności absorpcyjnej, „E-Mentor” (oddano do druku).

[21] Tortoriello M. (2015), The Social Underpinnings of Absorptive Capacity: The Moderating Effects of Structural Holes on Innovation Generation Based on External Knowledge, „Strategic Management Journal", Vol. 36, No. 4, 586-597.

[22] Yli-Renko H., Autio E., Sapienza H.J. (2001), Social Capital, Knowledge Acquisition, Knowledge Exploitation in Your Technology-based Firm, „Strategic Management Journal”, Vol. 22, No. 6/7, pp. 587-613.

[23] Zahra S.A., George G. (2002), Absorptive Capacity: A Review, Reconceptualization, and Extension, „Academy of Management Review", Vol. 27, No. 2, pp. 185-203.

\section{Mediation Effects in the Context of External Knowledge Acquisition and Exploitation as Success Factors in Development of Organisation}

\section{Summary}

The deliberations presented in this article revolve around the concept of absorptive capacity. The authors concentrated on making the mechanism of knowledge transfer more precise and accurate from its acquisition to exploitation - the mechanism owing to which new external knowledge is integral to organisational memory and structure. In relation to this, the aim of these deliberations was to investigate the relationships that would occur between acquisition and exploitation of external knowledge, while considering the role of assimilation and transformation of this category of resource. In order to verify the research hypotheses a series of regression analyses were performed, which were then used to test mediation effects.

The aim of the project was accomplished, revealing statistically important relationship between acquisition and exploitation of external knowledge. It was also ascertained that assimilation and transformation of external knowledge are essential mediators of this relationship. Double mediation significantly affects the relationship between an independent variable and dependent variable. It means that knowledge acquisition from external sources (independent variable) causes increase in assimilation of this resource (first mediator), as a result of which transformation of assimilated knowledge (second mediator), and because of that the increase in its exploitation becomes visible (dependent variable).

\section{Keywords}

knowledge acquisition, exploitation, absorptive capacity, mediation 